\title{
Pengukuran Aktivitas Pemasaran pada Media Sosial Instagram
}

\author{
Arie Indra Gunawan ${ }^{1, *}$, Fatya Alty Amalia ${ }^{2}$, Widi Senalasari ${ }^{3}$, Vanessa Gaffar ${ }^{4}$ \\ 1,2,3 Program Studi Sarjana Terapan Manajemen Pemasaran, Politeknik Negeri Bandung, \\ Bandung, Indonesia \\ ${ }^{4}$ Program Studi Manajemen, Fakultas Pendidikan Ekonomi Bisnis, Universitas Pendidikan Indonesia, \\ Bandung, Indonesia \\ *Email: arie.indra@polban.ac.id
}

\begin{abstract}
This study aims to measure and validate the variable constructs of marketing activity in Instagram social media. The results of this study will be very meaningful for the study and implementation of measurement of marketing activity in Instagram social media because currently Instagram is a social media that has a large customer base and has activity business therein. This study uses a questionnaire as a means of collecting data that is sent online. The population in this study were social media users who had done online transactions on Instagram social media as many as 352 respondents' data were collected which were then performed statistical calculations. Confirmatory Factor analysis (CFA) and Exploratory Factor Analysis (EFA) were conducted to measure marketing activities on Instagram social media. The results recommend that the variable marketing activity on Instagram social media can be measured through 6 dimensions consisting of 20 indicator items. These dimensions are visual communication, relationship interaction, delivery of information, recommendations, personalization, and modern elements. All these dimensions and indicators are in construct and consistency declared valid for measuring Instagram social media marketing activities.
\end{abstract}

Abstraksi: Penelitian ini bertujuan untuk mengukur dan memvalidasi konstruk variabel aktivitas pemasaran dalam media sosial instagram. Hasil penelitian ini akan sangat berarti untuk kajian dan implementasi pengukuran aktivitas pemasaran dalam media sosial instagram karena saat ini instagram merupakan media sosial yang memiliki basis pelanggan yang banyak dan terdapat aktivitas bisnis di dalamnya. Penelitian ini menggunakan kuesioner sebagai alat pengumpul data yang dikirimkan secara online. Populasi pada penelitian ini adalah pengguna media sosial yang pernah melakukan transaksi online di media sosial Instagram sebanyak 352 data responden berhasil terkumpul yang kemudian dilakukan penghitungan statistik. Confirmatory Factor Analysis (CFA) dan Exploratory Factor Analysis (EFA) dilakukan untuk mengukur aktivitas pemasaran dalam media sosial instagram. Hasil penelitian merekomendasikan bahwa variable aktivitas pemasaran pada media sosial instagram dapat diukur melalui 6 dimensi yang terdiri dari 20 item indikator. Dimensi tersebut adalah komunikasi visual, interaksi relasi, penyampaian informasi, rekomendasi, personalisasi, dan unsur modern. Kesemua dimensi dan indikator tersebut secara konstruk dan konsistensi dinyatakan valid untuk mengukur aktivitas pemasaran media sosial instagram.

Kata Kunci: Aktivitas Pemasaran; E-commerce; Instagram; Media Sosial

\section{Pendahuluan}

Perkembangan teknologi dan media informasi membuat kegiatan e-commerce semakin berkembang secara cepat. Tidak hanya dalam platform khusus penjualan seperti website dan marketplace saja, tetapi juga merambah pada platform media sosial. Interaksi yang intensif dalam media sosial merupakan peluang baru dalam komunikasi pemasaran. Komunikasi dua arah yang terjadi dapat digunakan oleh perusahaan untuk mengomunikasikan produknya, sementara audience dapat berperan sebagai konsumen dan pelanggan yang memerima informasi produk. Terdapat dua alasan utama perusahaan mengolaborasikan aktivitas $e$ commerce dengan media social, yang pertama yaitu perusahaan menggunakan media sosial untuk menciptakan keunggulan kompetitifnya. Penggunaan media sosial ini dapat mempertajam komunikasi pemasaran yang dilakukan dan menciptakan sebuah cara baru dalam komunikasi pemasaran digital (Valos et al., 2017). Alasan kedua adalah bahwa media sosial memiliki basis pelanggan yang sangat potensial bagi perusahaan karena memiliki jumlah pengguna yang sangat banyak. Oleh karena itu, perusahaan memanfaatkan media sosial sebagai salah satu sarana media 
komunikasi pemasaran (Yadav \& Rahman, 2017). Sementara itu, dalam sudut pandang konsumen, media sosial telah dinyatakan sebagai salah satu penyedia informasi dan rujukan pelanggan dalam pencarian produk, sebanyak $93 \%$ pengguna media sosial melakukan pencarian informasi untuk pembelian produk dan jasa (We Are Social, 2019).

Media sosial telah menjadi bagian yang tidak terpisahkan dari kehidupan modern dengan berbagai kemudahan yang terjadi karena adanya teknologi informasi semakin membuat variatif ragam jenis dari media interaksi sosial. Perkembangan jenis media sosial tersebar dalam berbagai platform dan karakteristik. Media sosial seperti Facebook, Twitter, Linked In, YouTube, WhatsApp, Instagram, Tumblr, Pinterest, We Chat dan Google, memberikan peluang untuk berinteraksi dan berkomunikasi secara bebas, serta bertukar konten informasi (Duffett, 2017). Media sosial menjadi sebuah ruang untuk menjalin komunikasi dan memberikan alternatif untuk pencarian informasi dan menentukan keputusan (Gunawan et al., 2020). Perkembangan media sosial baik dari ragam jenis karakteristik maupun dari jumlah pengguna yang terus bertambah secara signifikan telah membuat pola komunikasi pemasaran yang baru sehingga menjadikan media sosial sebagai media yang penting dalam aktivitas bisnis. Media sosial memberikan tiga keuntungan kompetitif dari segi komunikasi pemasaran yaitu mengarahkan pembeli ke produk baru, memberikan kesepakatan yang menarik bagi kedua belah pihak, serta mampu menciptakan keterlibatan yang tinggi antara pelanggan dengan perusahaan (Belch \& Belch, 2018). Tren e-commerce dengan menggunakan media sosial semakin meningkat karena memudahkan komunikasi dua arah antara perusahaan dan pelanggan, dalam perspektif pelanggan menjadikan media sosial sebagai salah satu media yang paling sering digunakan dan menjadikan media ini sebagai salah satu cara yang paling disukai untuk membeli barang (Yadav \& Rahman, 2017).
Berdasarkan hasil penelitian yang dilakukan oleh asosiasi $e$-commerce Indonesia (idEA), media sosial merupakan platform yang paling sering digunakan dalam melakukan transaksi e-commerce, transaksi online pada media sosial mencapai $66 \%$ (Databoks, 2017). Angka ini menunjukkan media sosial merupakan salah satu media yang paling diminati dalam aktivitas e-commerce, tetapi masih sedikit studi yang mengukur mengenai aktivitas pemasaran dalam media sosial tersebut (Yadav \& Rahman, 2017). Bisnis yang menggunakan media sosial merupakan suatu hal yang sangat berbeda dengan kegiatan bisnis elektronik pada umumnya karena memiliki karakteristik konsumen dan media yang berbeda. Oleh karena itu, terdapat kebutuhan untuk mengembangkan konsep mengenai aktivitas ini khususnya dalam aspek marketing content dan copywriting yang dilakukan dalam media sosial. Banyak peneliti sebelumnya seperti Lu et al. (2016), dan Yadav \& Rahman (2017) yang merekomendasikan beragam perspektif aktivitas pemasaran media sosial di berbagai industri. Namun meskipun komponen media sosial telah banyak dimasukkan dalam kegiatan e-commerce efektifitasnya jarang dievaluasi dan dikonfirmasi dalam literatur (Lu et al., 2016). Semakin berkembangnya kegiatan e-commerce melalui media sosial maka terdapat kesenjangan akan hal tersebut. Dibutuhkan sebuah kajian yang mempelajari kegiatan social media marketing activities (SMMA). Pemahaman tentang perspektif aktivitas pemasaran media sosial dalam kegiatan e-commerce sangat penting karena akan menawarkan pandangan dan wawasan baru mengenai bidang studi manajemen pemasaran yang membahas mengenai media sosial dan e-commerce. Secara umum penelitian ini memiliki tujuan untuk mengukur dan memvalidasi konstruk variabel aktivitas pemasaran media sosial Instagram yang melakukan aktivitas transaksi online (ecommerce).

\section{Kajian Literatur}

Media sosial sangat erat hubungannya dengan Web 2.0, tempat dimana konten secara terus menerus dilakukan pengembangan oleh 
semua platform dengan cara berbagi dan berkolaborasi (Sutrisno et al., 2020). Media sosial dibangun di atas pondasi teknologi Web 2.0 yang memungkinkan pembuatan dan pertukaran konten yang dibuat oleh masingmasing pengguna. Berbagai faktor dan keunggulan media sosial dalam konteks relationship telah diidentifikasi seperti kemudahan membagikan ide, kegiatan atau acara pada orang lain, serta media ini memiliki keterlibatan sosial yang tinggi. Penelitian dalam bidang media sosial ini masih menjadi daya tarik karena ruang lingkupnya menyangkut karakteristik tiap-tiap platform dan perilaku konsumen yang sangat unik (Belch \& Belch, 2018). Media sosial diakui sebagai salah satu platform komunikasi terpenting dalam kegiatan bisnis untuk menciptakan hubungan dan komunikasi dua arah dengan pelanggan. Fitur media sosial yang interaktif memungkinkan kegiatan partisipatif, kolaboratif, dan berbagi pengetahuan terjadi sehingga akan semakin mempermudah penyebaran informasi (Knoll, 2016). Kajian mengenai media sosial yang digunakan untuk aktivitas bisnis (e-commerce) dirasakan penting bagi perkembangan bisnis karena perkembangan teknologi dan perubahan perilaku konsumen saat ini menjadikan dominasi media sosial semakin menguat dan pengguna media sosial semakin banyak. maka muncul social media marketing.

Social media marketing activities merupakan kegiatan pemasaran yang melibatkan platform media sosial sebagai media dalam membangun hubungan yang bersifat dua arah yang memungkinkan terjadinya keterlibatan yang tinggi antara kedua belah pihak (Stephen, 2016). Social media marketing merupakan proses dimana perusahaan membuat, berkomunikasi, dan memberikan penawaran pemasaran online melalui platform media sosial untuk membangun dan memelihara hubungan dengan memfasilitasi interaksi, berbagi informasi, penawaran, dan penciptaan $e$-Wom di antara para followers tentang suatu produk ataupun tentang sebuah trend (Yadav \& Rahman, 2017). Social media marketing umumnya diakui memainkan peran yang cukup besar dalam mempengaruhi persepsi konsumen terhadap produk dan merek. Kegiatan social media marketing dianggap lebih berpengaruh daripada komunikasi pemasaran tradisional (Cheung et al., 2019). Berdasarkan beberapa kajian yang dilakukan terlihat bahwa media sosial merupakan platform yang potensial dalam menunjang kegiatan bisnis dan juga aktivitas pemasaran. Untuk mendapatkan gambaran yang lebih luas maka penulis membandingkan beberapa konsep social media marketing untuk dapat merumuskan beberapa dan dimensi inti yang tekandung dalam aktivitas social media marketing khususnya dalam media sosial Instagram.

Tabel 1. Definisi Konsep Social Media Marketing

\begin{tabular}{|c|c|c|c|}
\hline No & Author & Definisi & Fokus \\
\hline 1 & $\begin{array}{l}\text { Belch dan } \\
\text { Belch } \\
(2018)\end{array}$ & $\begin{array}{l}\text { Cara perusahaan } \\
\text { merencanakan, } \\
\text { mengembangkan, } \\
\text { dan melaksanakan } \\
\text { program komunikasi } \\
\text { pemasaran mereka. }\end{array}$ & $\begin{array}{c}\text { Komunikasi, } \\
\text { interaksi }\end{array}$ \\
\hline 2 & $\begin{array}{l}\text { Choi et } \\
\text { al. (2016) }\end{array}$ & $\begin{array}{l}\text { Penciptaan informasi } \\
\text { dari mulut ke mulut, } \\
\text { secara positif } \\
\text { memengaruhi ekuitas } \\
\text { pelanggan, } \\
\text { meningkatkan } \\
\text { loyalitas pelanggan } \\
\text { kepada perusahaan, } \\
\text { meningkatkan niat } \\
\text { beli. }\end{array}$ & $\begin{array}{c}\text { Rekomendasi, } \\
\text { informasi, } \\
\text { Word of } \\
\text { Mouth }\end{array}$ \\
\hline 3 & $\begin{array}{l}\text { Yadav } \\
\text { dan } \\
\text { Rahman } \\
(2017)\end{array}$ & $\begin{array}{l}\text { Proses dimana } \\
\text { perusahaan } \\
\text { membuat, } \\
\text { berkomunikasi, dan } \\
\text { memberikan } \\
\text { penawaran } \\
\text { pemasaran online } \\
\text { melalui platform } \\
\text { media sosial untuk } \\
\text { membangun dan } \\
\text { memelihara } \\
\text { hubungan pemangku } \\
\text { kepentingan }\end{array}$ & $\begin{array}{c}\text { Personalisasi, } \\
\text { Interaksi, dan } \\
\text { Informasi }\end{array}$ \\
\hline 4 & $\begin{array}{l}\text { Cheung } \\
\text { et al. } \\
(2019)\end{array}$ & $\begin{array}{l}\text { Elemen dalam } \\
\text { membangun } \\
\text { pengetahuan merek } \\
\text { yang kuat dan } \\
\text { menguntungkan di } \\
\text { benak konsumen }\end{array}$ & Informasi \\
\hline 5 & $\begin{array}{l}\text { Knoll } \\
(2016)\end{array}$ & $\begin{array}{l}\text { Salah satu } \\
\text { komunikasi } \\
\text { terpenting untuk } \\
\text { informasi merek } \\
\text { karena fitur } \\
\text { interaktifnya } \\
\text { memungkinkan } \\
\text { kegiatan partisipatif, } \\
\text { kolaboratif, dan } \\
\text { berbagi pengetahuan. }\end{array}$ & $\begin{array}{c}\text { Komunikasi } \\
\text { informasi }\end{array}$ \\
\hline
\end{tabular}

Sumber: Olah Data Penulis (2020) 
Berdasarkan kajian literatur yang dilakukan, definisi social media marketing belum mencapai kesepakatan kolektif karena terdapat banyak perspektif yang disampaikan. Hal ini terjadi karena ruang lingkup social media marketing dapat dikaji dari multidimensi yaitu dimensi komunikasi sosial, dimensi pemasaran, dan dimensi hubungan jaringan. Media sosial merupakan platform yang paling banyak digunakan dalam transaksi online. Sebanyak $66 \%$ transaksi online terjadi di platform media sosial (Databoks, 2017). Hal ini mengindikasikan bahwa pembeli dan penjual dalam aktivitas $e$ commerce sangat mengandalkan media sosial untuk berinteraksi dan melakukan transaksi jual beli. Dari berbagai jenis media sosial yang ada terdapat salah satu platform yang memiliki karakteristik unik yakni berbasis grafis, foto, dan video, yakni Instagram. Media sosial Instagram juga memiliki tingkat customer base yang sangat tinggi. Berdasarkan definisi sosial media marketing yang populer dalam industri dan akademisi yang telah dirangkum penulis, terdapat beberapa fokus utama yang dapat dijadikan rujukan dalam pengukuran variabel aktivitas social media marketing, fokus utama tersebut adalah komunikasi visual (Belch \& Belch, 2018), interaksi relasi (Kietzmann et al., 2011; Yadav \& Rahman, 2017), penyampaian informasi (Belch \& Belch, 2018), rekomendasi (WOM) (Choi et al., 2016), personalisasi (Yadav \& Rahman, 2017), dan unsur aktual informasi (modern). Fokus utama yang telah dirangkum ini selanjutnya

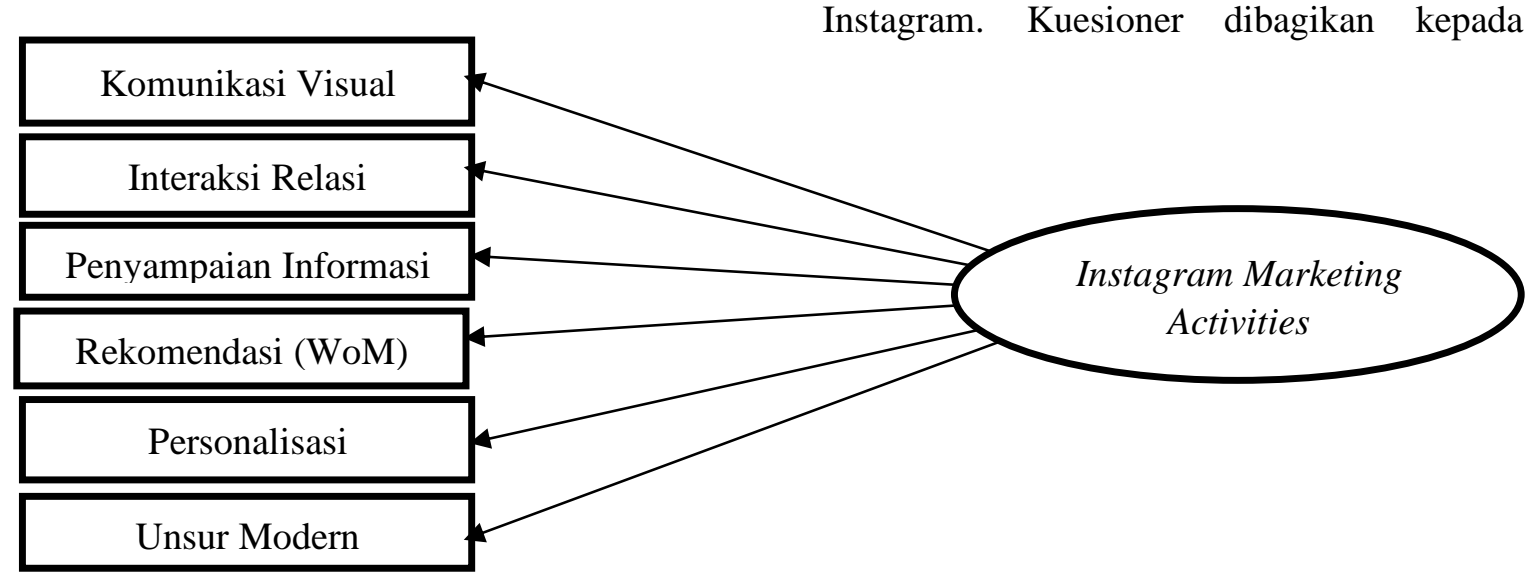

dirumuskan dalam sebuah model untuk dilakukan pengujian konstruk variabel sosial media marketing activity.

Berdasarkan hasil kajian literatur dan hasil analisis pakar awal dirumuskan bahwa variabel Instagram marketing activities dapat diwakili oleh beberapa faktor. Faktor-faktor ini diperoleh dari kajian empiris aktivitas pemasaran yang dilakukan dalam social media Instagram. Kajian empiris melihat bahwa aktivitas pemasaran pada media sosial

Instagram berbeda dengan karakteristik media sosial lainnya. Karaktersitik media sosial Instagram memiliki multidimensi yaitu komunikasi sosial, komunikasi pemasaran, dan dimensi hubungan jaringan. Penelitian ini akan mengukur aktivitas sosial media Instagram yang diukur dari enam dimensi yaitu komunikasi visual, interaksi relasi, penyampaian informasi, rekomendasi (wom), personalisasi, dan unsur modern yang merupakan pengembangan dari beberapa penelitian terdahulu yang dilakukan.

\section{Metode Penelitian}

Penelitian ini dilakukan untuk mengukur dan memvalidasi konstruk variabel aktivitas pemasaran pada media sosial Instagram. Penelitian dilakukan dengan menggunakan pendekatan kuantitatif dengan bantuan kuesioner sebagai alat pengumpul data yang disebarkan secara online. Populasi yang dijadikan responden penelitian adalah pengguna media sosial yang pernah melakukan aktivitas transaksi di media Instagram. Kuesioner dibagikan kepada

\section{Gambar 1. Konstruk Model}


penguna media Instagram yang mengikuti akun instagram bisnis, pengambilan data dilakukan dari bulan April hingga Juli 2020.

Indikator dalam penelitian ini diukur dengan menggunakan skala likert lima poin. Untuk memastikan kuesioner sesuai untuk mengukur variable dilakukan penilaian oleh akademisi dan peneliti bidang ilmu pemasaran sebelum menyebarkan kuesioner. Sebanyak 352 data terkumpul dan menyisakan 326 data yang dapat dianalisis lebih lanjut. Terdapat 6 kelompok dimensi yang terdiri dari 24 unsur social media marketing activities yang kemudian dilakukan analisis faktor, alur penelitian diilustrasikan pada Gambar 2.

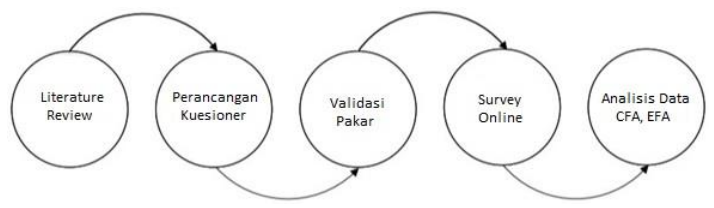

\section{Gambar 2. Alur Penelitian}

Pengukuran konstruk varibel aktivitas pemasaran media sosial Instagram dilakukan dalam dua metode analisis data yaitu Exploratory Factor Analysis (EFA) dan Confirmatory Factor Analysis (CFA). EFA dilakukan dengan menggunakan metode Principal Component Analysis dan Varimax Kaiser Normalization. CFA diidentifikasi melalui pengukuran reliabilitas konstruk yang dihitung dengan Average Variance Extracted (AVE), dan Composite Reliability (CR) instrumen. Average Variance Extracted digunakan untuk mengukur seberapa banyak varians dalam indikator yang disediakan dapat ditangkap oleh konstruksi dimensi yang diujikan. Berdasarkan Hair et al (2016) nilai AVE yang baik harus di atas 0,5. AVE dapat dihitung dengan rumus:

$$
A V E=\frac{\sum \lambda i^{2}}{\lambda i^{2}+\sum i \operatorname{var}(\varepsilon i)}
$$

Koefisien $\lambda i$ menunjukkan banyaknya faktor loading ke indikator dan var.

Selain AVE yang digunakan untuk mengukur konstruk adalah penghitungan Composite Reliability. Penghitungan CR perlu dilakukan untuk mengetahui konsistensi internal dari variabel yang diukur. Semakin tinggi angka yang ditunjukkan CR maka semakin baik konsistensi masing-masing indikator dalam mengukur konstruk yang diusulkan. Untuk mendapatkan nilai reliabilitas yang baik nilai, CR yang diharapkan harus lebih dari 0,7 (Hair, J.F., Hult, G.T.M., Ringle, C., Sarstedt, 2016). Rumus yang digunakan untuk menghitung Composite Reliability adalah:

$$
C R=\frac{\left(\sum \lambda i\right)^{2} \rho c}{\left(\sum \lambda i\right)^{2}+\sum i \operatorname{var}(\varepsilon i)}
$$

Koefisien $\lambda \mathrm{i}$ menunjukkan banyaknya faktor loading ke indikator, dan var (ci).

\section{Hasil Penelitian}

Perhitungan statistik dilakukan dengan menggunakan bantuan software SPSS. Berdasarkan hasil perhitungan yang berkaitan dengan metode Exploratory Factor Analysis (EFA) terhadap variabel social media Instagram marketing activities melibatkan dua jenis output yaitu KMO and Bartlett's test dan output dari Rotated Component Matrix. Hasil tersebut dirangkum dalam Tabel 2 Hasil Uji KMO dan Bartlett dan Tabel 3 menunjukkan Hasil Rotated Component Matrix.

\section{Tabel 2 Hasil KMO and Bartlett's test}

\begin{tabular}{ccc}
\hline \multicolumn{3}{c}{ Kaiser-Meyer-Olkin Measure of } \\
Sampling Adequacy. & 0.875 \\
\hline & Approx. Chi- & 3.780 \\
Bartlett's Test of & Square & 171 \\
Sphericity & df & 171 \\
& Sig. & 0.000 \\
\hline
\end{tabular}

Sumber: Olah Data SPSS (2020)

Tabel 2 menunjukkan hasil KaiserMeyer-Olkin Measure (KMO) dari Sampling Adequacy penelitian ini. KMO memiliki nilai signifikan 0,000, Chi-Square 3,780 derajat kebebasan 171, dan nilai KMO yang tinggi lebih dari 0,50. Menurut Hair et al., (2017) hasil tersebut merupakan nilai yang dapat diterima. Hasil uji KMO dan Bartlett ini menunjukkan adanya korelasi antar variabel dan layak untuk dianalisis lebih lanjut. Tabel 3 menunjukkan hasil metode Rotated Component Matrix dengan enam faktor baru yang terbentuk. Faktor pertama adalah komunikasi visual yang terdiri dari empat 
indikator. Faktor kedua adalah interaksi relasi yang terdiri dari tiga indikator. Faktor ketiga penyampaian informasi terdiri dari tiga indikator. Faktor keempat rekomendasi diwakili tiga indikator. Faktor kelima personalisasi tiga indikator, dan terakhir adalah sifat modern yang diwakili oleh tiga indikator. Hasil penghitungan statistik menyatakan terdapat empat indikator yang memiliki loading factor dibawah cut-of-value 0,6 yaitu "memberikan sugesti positif" yang merupakan salah satu indikator dimensi komunikasi visual, "interaksi secara langsung" yang merupakan indikator dimensi interaksi relasi, dan "informasi komprehensif" yang merupakan bagian dari dimensi penyampaian informasi, dan indikator "referensi sangat mudah" yang merupakan bagian dari rekomendasi. Keempat indikator tersebut dihapus dari masing-masing faktor. Hasil EFA lain diperoleh dari analisis adalah Eigen Value, Explained Variance, Cumulative Variance Explained dan Cronbach's Alpha.
Varian total yang dapat dijelaskan oleh kelima faktor tersebut adalah $72,567 \%$. Faktor pertama adalah komunikasi visual yang diwakili oleh empat item yang dapat menjelaskan varians sebesar $33,17 \%$. Faktor kedua dapat disebut sebagai interaksi-relasi direpresentasikan oleh tiga item memberikan kontribusi terhadap varians sebesar $15,76 \%$. Faktor ketiga penyampaian informasi yang semula terdiri dari empat item hanya dapat diwakili oleh tiga item karena satu item memiliki loading faktor di bawah 0,6, Faktor penyampaian informasi dapat menjelaskan varians sebesar $7,18 \%$. Faktor keempat yaitu rekomendasi yang diwakili oleh tiga indikator mampu menjelaskan varians sebesar $6,285 \%$. Faktor kelima yaitu personalisasi yang diwakili oleh tiga indikator mampu menjelaskan varians sebesar 5\%. Faktor terakhir yaitu kekinian diwakili oleh tiga item memberikan kontribusi terhadap variable sebesar 4,157\%. Hasil penghitungan Cronbach alpha secara keseluruhan dari keenam faktor Instagram

Tabel 3. Hasil Rotated Component Matrix

\begin{tabular}{|c|c|c|c|c|c|c|}
\hline \multirow[t]{2}{*}{ Indicators } & \multicolumn{6}{|c|}{ Component } \\
\hline & $\begin{array}{l}\text { Komunikasi } \\
\text { Visual }\end{array}$ & $\begin{array}{l}\text { Interaksi } \\
\text { Relasi }\end{array}$ & $\begin{array}{l}\text { Penyampaian } \\
\text { Informasi }\end{array}$ & Rekomendasi & Personalisasi & $\begin{array}{l}\text { Unsur } \\
\text { Modern }\end{array}$ \\
\hline Copy Writing menarik perhatian & 0.802 & & & & & \\
\hline Content mudah dipahami & 0.831 & & & & & \\
\hline $\begin{array}{l}\text { Menunjukan keunggulan } \\
\text { produk }\end{array}$ & 0.729 & & & & & \\
\hline $\begin{array}{l}\text { Visualisasi mengandung } \\
\text { kreativitas }\end{array}$ & 0.713 & & & & & \\
\hline Interaksi mengikat hubungan & & 0.855 & & & & \\
\hline Interaksi bersifat dua arah & & 0.763 & & & & \\
\hline Interaksi secara responsif & & 0.864 & & & & \\
\hline Informasi factual dan objektif & & & 0.736 & & & \\
\hline Informasi bermanfaat & & & 0.713 & & & \\
\hline Informasi dapat dipercaya & & & 0.721 & & & \\
\hline $\begin{array}{l}\text { Mudah } \\
\text { merekomendasi/direkomendasi }\end{array}$ & & & & .814 & & \\
\hline $\begin{array}{l}\text { Mendorong orang lain } \\
\text { mengakses }\end{array}$ & & & & .813 & & \\
\hline $\begin{array}{l}\text { Sharing konten efektif dalam } \\
\text { berjejaring }\end{array}$ & & & & .771 & & \\
\hline $\begin{array}{l}\text { Pembelian disesuaikan } \mathrm{dg} \\
\text { keinginan }\end{array}$ & & & & & 0.828 & \\
\hline Kebutuhan terpenuhi & & & & & 0.813 & \\
\hline Pencarian sesuai keinginan & & & & & 0.799 & \\
\hline $\begin{array}{l}\text { Sangat bermanfaat melakukan } \\
\text { pencarian }\end{array}$ & & & & & 0.740 & \\
\hline Konten merupakan tren terbaru & & & & & & 0.774 \\
\hline Media yang sesuai dengan & & & & & & 0.745 \\
\hline $\begin{array}{l}\text { kebutuhan } \\
\text { Mencakup semua yang sedang } \\
\text { trend }\end{array}$ & & & & & & 0.714 \\
\hline Eigenvalue & 6.302 & 2.997 & 1.364 & 1.194 & 0.950 & 0.790 \\
\hline Variance explained $\%$ & 33.170 & 15.775 & 7.179 & 6.285 & 5.001 & 4.157 \\
\hline $\begin{array}{l}\text { Cumulative variance explained } \\
\%\end{array}$ & 33.170 & 48.944 & 56.124 & 62.408 & 67.409 & 72.567 \\
\hline Cronbach's Alpha & 0.751 & 0.744 & 0.723 & 0.754 & 0.763 & 0.743 \\
\hline
\end{tabular}

Sumber: Olah Data SPSS (2020) 
social media marketing activities memiliki nilai diatas 0,7 yang menunjukkan nilai reliabilitas yang baik. Pengukuran statistik dari uji kebulatan Bartlett ( $\mathrm{p}<0,01)$ dan uji Kaiser-Meyer-Olkin $(0,875)$ berarti bahwa sampel yang digunakan dalam penelitian dianggap mewakili populasi.

\section{Tabel 4. Indentifikasi Dimensi}

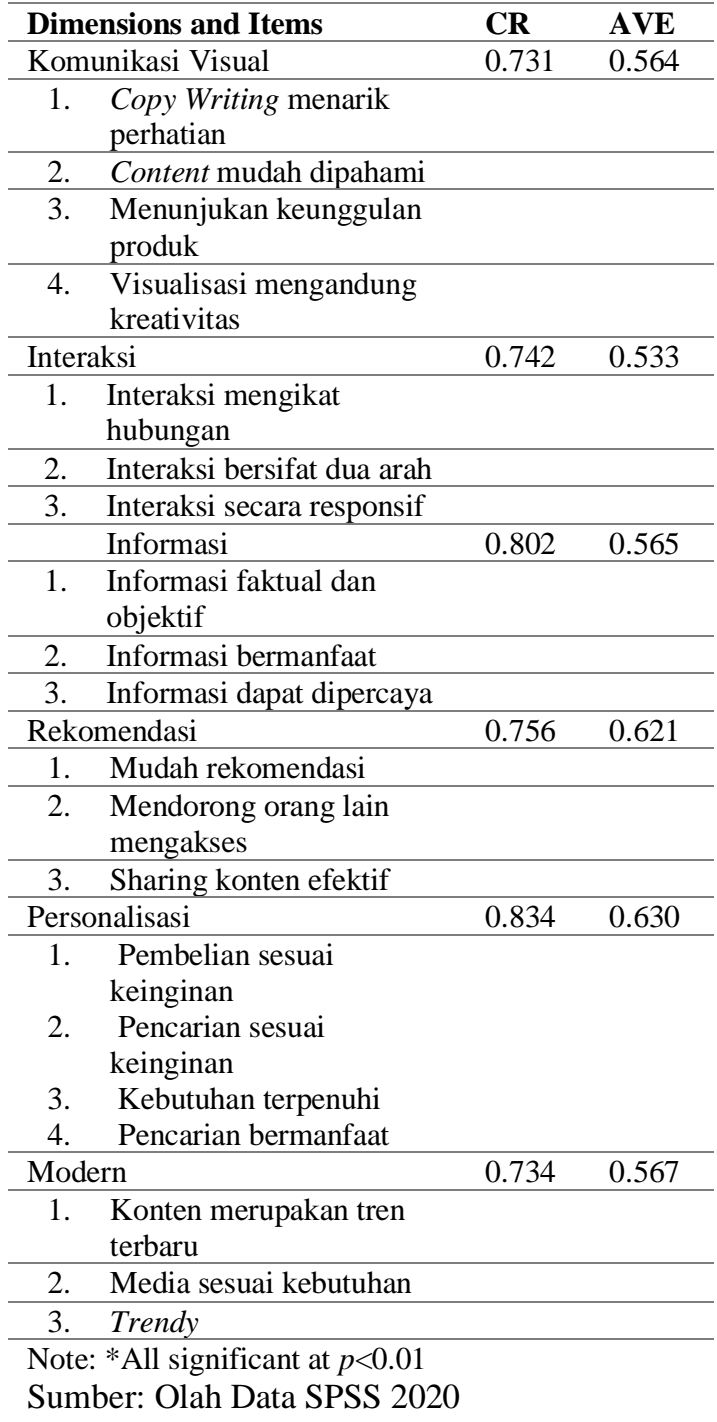

Langkah selanjutnya adalah melakukan Confirmatory Factor Analysis (CFA). Tujuan dari analisis ini adalah untuk memverifikasi struktur faktor dari dimensi yang ada pada variabel aktivitas pemasaran sosial media. Analisis ini juga untuk memastikan bahwa indikator merupakan bagian dari faktor tertentu dan bukan bagian dari faktor lain. Analisis CFA melalui proses penghitungan Construct Reliability (CR) dan Average Variance Extracted (AVE). Hasil CFA ditunjukkan pada Tabel 4. Tabel 4 menunjukkan soal-soal yang diuji menggunakan CFA melibatkan enam kelompok faktor yang terdiri dari 20 indikator. Semua faktor tersebut dianggap relevan dalam mengukur variabel aktivitas pemasaran media sosial Instagram dan memiliki nilai konsistensi internal yang baik. Hal ini disebabkan oleh hasil Composite Reliability dan Average Variance Extracted memenuhi kriteria CR lebih tinggi dari 0,7 dan AVE di atas 0,5 .

\section{Pembahasan}

Penelitian sebelumnya yang serupa dengan penelitian ini adalah Yadav \& Rahman (2017) yang membahas penelitian tentang aktivitas media pemasaran dalam e-commerce dan penelitian dari Cheung et al., (2019) yang membahas tentang komunikasi pemasaran media sosial terhadap pengetahuan merek konsumen. Konteks penelitian yang dilakukan oleh penulis berbeda dengan penelitian terdahulu karena penelitian yang dilakukan oleh penulis merupakan pengembangan konstruk variabel aktivitas pemasaran yang spesifik membahas aktivitas pemasaran di media sosial Instagram. Kemudian perbedaan lainnya adalah faktor-faktor yang digunakan. Faktor-faktor pembentuk variabel yang digunakan dalam penelitian ini merupakan pembentuk aktivitas pemasaran sosial media yang terdiri dari multidimensi, yakni komunikasi sosial, dimensi pemasaran, dan dimensi hubungan jaringan yang menghasilkan enam dimensi yaitu komunikasi visual, interaksi relasi, penyampaian informasi, rekomendasi (wom), personalisasi, dan unsur modern yang merupakan pengembangan dari beberapa penelitian terdahulu yang dilakukan.

Berdasarkan hasil penelitian yang telah dilakukan, untuk mengukur aktivitas pemasaran pada media sosial Instagram dapat dilakukan melalui konstruk yang terdiri dari 20 indikator yang tergabung kedalam enam dimensi utama yaitu komunikasi visual, interaksi-relasi, penyampaian informasi, rekomendasi (wom), personalisasi, dan sifat modern (actual). Dimensi konten komunikasi visual mengukur bagaimana komunikasi melalui desain visual dan komunikasi tulisan 
diinterpretasi oleh audience (Shimp \& Andrews, 2013) yang dalam hal ini adalah pengguna Instagram sehingga melalui dimensi ini dapat terukur bagaimana konten secara visual dan tulisan dalam setiap postingan Instagram (Evans et al., 2017). Interaksi-relasi menggambarkan bagaimana platform ini dinyatakan sebagai media yang mengikat hubungan antara pembeli dan penjual (Yadav \& Rahman, 2017). Kemudian pengukuran aktivitas pemasaran juga diukur melalui tingkat penyampaian informasi karena informasi adalah muatan dalam setiap aktivitas pemasaran dan inti dari komunikasi yang dilakukan oleh penjual kepada calon pembeli (Cheung et al., 2019). Rekomendasi menjadi ukuran lainnya karena kekuatan utama media sosial adalah berjejaring (Gunawan et al., 2020) sehingga perlu dilakukan pengukuran berdasarkan persepsi pengguna bagaimana meraka dapat merekomendasikan atau direkomendasikan oleh orang lain (Choi et al., 2016). Selanjutnya aspek personalisasi merupakan hal terpenting dalam aktivitas pemasaran (Belch \& Belch, 2018). Dalam hal ini personalisasi menggambarkan tingkat pencarian informasi dan pemenuhan kebutuhan dan keinginan apakah dapat disesuaikan dengan karakteristik calon pembeli. Dimensi terakhir yang teridentifikasi sebagai faktor pelengkap dalam aktivitas pemasaran merupakan keseuaian dengan platform media Instagram, yakni mengukur unsur modern dari platform instagram sebagai media sosial yang trendy dan kekinian.

\section{Kesimpulan}

Media sosial dinilai sebagai sarana yang efektif untuk melakukan kegiatan pemasaran karena berfokus langsung pada segmen pasar sasaran yang sudah jelas dan tegas yakni follower sebagi customer based. Dengan begitu pihak penjual dapat melakukan penyampaian informasi yang lebih efektif dan tepat sasaran serta dapat berinteraksi dan membagikan pengalaman secara langsung. Saat ini media sosial Instagram merupakan platform yang paling banyak digemari, Instagram yang awalnya berfungsi sebagai media berjejaring perlahan berubah menjadi sarana promosi, aktivitas bisnis, hingga $e$ commerce. Karakteristik dan berbagai fitur yang dimiliki oleh Instagram menjadikan platform ini menjadi salah satu media sosial yang paling banyak digunakan termasuk dalam aktivitas pemasaran hingga terjadinya transaksi jual beli. Meningkatnya aktivitas pemasaran yang dilakukan dalam media sosial Instagram menjadi sebuah daya tarik bagaimana komunikasi pemasaran yang sebaiknya dilakukan dalam media sosial Instagram. Berdasarkan penelitian konstruk aktivitas pemasaran pada media sosial media Instagram dapat diukur melalui 20 item. Konstruk yang diperoleh melalui pengukuran ini telah tervalidasi dan dapat digunakan untuk mengukur variabel aktivitas pemasaran media sosial Instagram sehingga dapat dijadikan salah satu acuan untuk menyusun program ataupun menyusun penelitian terkait social media marketing activities pada Instagram. Penelitian ini dilakukan dalam responden yang sangat terbatas dan dilakukan pada segmen usia tertentu. Hasil penelitian akan lebih baik jika respondennya merupakan pengguna Instagram secara umum atau bahkan dapat dibuat keterwakilan dari berbagai segmen usia dan berbagai kategori sektor produk yang ditawarkan di Instragram. Hal ini akan menjadi perhatian dan rekomendasi bagi peneliti lain yang akan melakukan penelitian serupa.

\section{Daftar Referensi}

Belch, G., \& Belch, M. (2018). Advertising and Promotion an Integrated Marketing Communication Perspectives. In Director (11th ed., Issue October). Mc Graw Hill Education.

Cheung, M. L., Pires, G. D., \& Rosenberger, P. J. (2019). Developing a conceptual model for examining social media marketing effects on brand awareness and brand image. International Journal of Economics and Business Research, 17(3), 243-261. https://doi.org/10.1504/IJEBR.2019.098 874

Choi, E. K. (Cindy), Fowler, D., Goh, B., \& Yuan, J. (Jessica). (2016). Social Media 
Marketing: Applying the Uses and Gratifications Theory in the Hotel Industry. Journal of Hospitality Marketing and Management, 25(7), 771-796.

https://doi.org/10.1080/19368623.2016. 1100102

Databoks. (2017). Media Sosial, Platform Paling Banyak Digunakan saat Transaksi e-commerce. In Databoks.Katadata.Co.Id. https://databoks.katadata.co.id/datapubli sh/2019/04/01/media-sosial-platformpaling-banyak-digunakan-saattransaksi-e-commerce

Duffett, R. G. (2017). Influence of social media marketing communications on young consumers' attitudes. Young Consumers, 18(1), 19-39. https://doi.org/10.1108/YC-07-201600622

Evans, N. J., Phua, J., Lim, J., \& Jun, H. (2017). Disclosing Instagram Influencer Advertising: The Effects of Disclosure Language on Advertising Recognition, Attitudes, and Behavioral Intent. Journal of Interactive Advertising, 17(2), 138149.

https://doi.org/10.1080/15252019.2017. 1366885

Gunawan, A. I., Najib, M. F., \& Setiawati, L. (2020). The effect of Electronic Word of Mouth (e-WoM) on social media networking. IOP Conference Series: Materials Science and Engineering, 830(3). https://doi.org/10.1088/1757899X/830/3/032002

Hair, J.F., Hult, G.T.M., Ringle, C., Sarstedt, M. (2016). A Primer on Partial Least Squares Structural Equation Modeling (PLS-SEM). SAGE Publications Inc. https://books.google.co.id/books?hl=id $\& 1 \mathrm{r}=\& \mathrm{id}=\mathrm{JDW} m \mathrm{CwAAQBAJ} \& \mathrm{i}=\mathrm{fnd}$ $\& p g=$ PP1 \&dq=Hair,+J.F.,+Hult,+G.T . M.,+Ringle,+C.,+Sarstedt,+M.+(2016). + A+Primer+on+Partial+Least+Squares + Structural+Equation+Modeling+(PLSSEM).+SAGE+Publications+Inc.\&ots= ejINLhEX-M\&sig=aIYC
Kietzmann, J. H., Hermkens, K., McCarthy, I. P., \& Silvestre, B. S. (2011). Social media? Get serious! Understanding the functional building blocks of social media. Business Horizons, 54(3), 241251.

https://doi.org/10.1016/j.bushor.2011.0 1.005

Knoll, J. (2016). Advertising in social media: A review of empirical evidence. International Journal of Advertising, $35(2)$, 266-300. https://doi.org/10.1080/02650487.2015. 1021898

Lu, B., Fan, W., \& Zhou, M. (2016). Social presence, trust, and social commerce purchase intention: An empirical research. Computers in Human Behavior, 56, 225-237. https://doi.org/10.1016/j.chb.2015.11.05 7

Shimp, A. T., \& Andrews, J. C. (2013). Integrated marketing communications. In South-Western, Cengage Learning (9th ed.). Cengage Learning. https://doi.org/10.4324/9780080942544

Stephen, A. T. (2016). The role of digital and social media marketing in consumer behavior. Current Opinion in Psychology, 10, 17-21. https://doi.org/10.1016/j.copsyc.2015.1 0.016

Sutrisno, R., Djatnika, T., \& Gunawan, A. I. (2020). Can SMEs Capture the Social Media Phenomenon?: CRM Strategies to Improve Relationship Performance. $1-8$.

https://doi.org/10.2991/aer.k.201221.02 0

Valos, M. J., Maplestone, V. L., Polonsky, M. J., \& Ewing, M. (2017). Integrating social media within an integrated marketing communication decisionmaking framework. Journal of Marketing Management, 33(17-18), 1522-1558.

https://doi.org/10.1080/0267257X.2017. 1410211 
We Are Social. (2019). Digital 2019: Indonesia. In Global Digital Insights. https://doi.org/https://datareportal.com/r eports/digital-2019-indonesia

Yadav, M., \& Rahman, Z. (2017). Measuring consumer perception of social media marketing activities in e-commerce industry: Scale development \& validation. Telematics and Informatics, 34(7), 1294-1307. https://doi.org/10.1016/j.tele.2017.06.00 